\title{
Glycerol as an Energy Source for Ruminants: A Meta-Analysis of in Vitro Experiments
}

\author{
T. M. Syahniar, ${ }^{\mathrm{a}, \mathrm{b}}$, M. Ridla ${ }^{\mathrm{c}}$, A. A. B. Samsudin', \& A. Jayanegaraa, ${ }^{\mathrm{c}, *}$ \\ ${ }^{a}$ Graduate School of Nutrition and Feed Science, Faculty of Animal Science, Bogor Agricultural University \\ bStudy Program of Animal Production, Polytechnic of Agriculture and Animal Science MAPENA \\ Jalan Raya Bojonegoro-Lasem Km. 32 Singgahan Tuban 62361, Indonesia \\ 'Department of Nutrition and Feed Technology, Faculty of Animal Science, Bogor Agricultural University \\ Jalan Agatis Kampus IPB Darmaga Bogor 16680, Indonesia \\ ${ }^{\mathrm{d}}$ Department of Animal Science, Faculty of Agriculture, University Putra Malaysia \\ Block C Agrobio Complex, Campus UPM Serdang-Selangor 43400, Malaysia \\ (Received 09-06-2016; Reviewed 21-07-2016; Accepted 03-10-2016)
}

\begin{abstract}
Glycerol or glycerin is generally recognized as a safe compound to be used in animal feed, especially for ruminants. A number of in vitro studies related to glycerol supplementation in ruminant ration have been published but to date the results have not been summarized. The objective of this study was, therefore, to evaluate in vitro digestibility, ruminal fermentation characteristics, total gas and methane production through the meta-analysis approach. Meta-analysis was applied to 13 experiments and 42 treatments dealing with glycerol supplementation in ruminants. Data were analyzed by general linear model procedure in which the glycerol levels and the different studies were treated as fixed effects. Results revealed that glycerol supplementation did not affect the in vitro digestibility and total VFA production, but significantly decreased molar proportion of acetate and iso-valerate $(\mathrm{P}<0.05)$. In contrast, molar proportion of propionate, butyrate, and valerate significantly increased, and thus the ratio of acetate to propionate declined linearly $(\mathrm{P}<0.05)$. Methane production decreased linearly and accompanied with an increase of total gas production with increasing levels of glycerol supplementation $(\mathrm{P}<0.05)$. It is concluded that the use of glycerol as an energy substitution in animal feed has no detrimental effects in the rumen and environmentally friendly.
\end{abstract}

Key words: fermentation, glycerol, in vitro, meta-analysis, ruminant

\section{ABSTRAK}

Secara umum gliserol aman digunakan di dalam pakan, khususnya untuk ternak ruminansia. Sejumlah eksperimen in vitro terkait suplementasi gliserol di dalam ransum ruminansia telah dipublikasikan tetapi hasilnya tidak konsisten. Tujuan penelitian ini adalah untuk mengevaluasi daya cerna in vitro, karakteristik fermentasi rumen, serta produksi gas total dan metana menggunakan metode meta-analisis. Meta-analisis secara kuantitatif mengenai suplementasi gliserol pada ruminansia diterapkan pada 13 studi dengan 42 perlakuan. Data untuk masing-masing variabel diestimasi melalui regresi linear dan dianalisis menggunakan metode GLM dengan level gliserol sebagai pengaruh tetapnya. Hasil menunjukkan bahwa suplementasi gliserol tidak berpengaruh terhadap daya cerna in vitro dan nilai VFA total, tetapi menurunkan produksi asam asetat dan isovalerat $(\mathrm{P}<0,05)$. Sebaliknya, terjadi peningkatan produksi asam propionat, butirat, dan valerat sehingga dapat menurunkan rasio antara asam asetat dan asam propionat $(P<0,05)$. Produksi metana menurun secara linear dan total produksi gas menunjukkan peningkatan yang signifikan seiring dengan peningkatan level gliserol yang digunakan $(P<0,05)$, tetapi tidak berpengaruh pada produksi protein mikrob. Dapat disimpulkan bahwa penggunaan gliserol sebagai pengganti sumber energi tidak memberikan pengaruh negatif di dalam rumen dan ramah lingkungan.

Kata kunci: fermentasi, gliserol, in vitro, meta-analisis, ruminansia

*Corresponding author:

E-mail: anu_jayanegara@yahoo.com 


\section{INTRODUCTION}

Biodiesel industry has grown rapidly along with the increasing demand of renewable and sustainable energy. Biodiesel is a liquid fuel that is obtained from natural lipids such as vegetable oil or animal fat using manufacturing processes of esterification and transesterification (Quispe et al., 2013). These processes produce a main by-product that is glycerol. Generally, glycerol production is up to 10 to $20 \%$ from the total volume of biodiesel produced. In the future, the amount of glycerol will be abundantly available and therefore it needs to be re-handled and re-used in order not to create a new environmental problem. On the other hand, high purity glycerol has been included in food, pharmaceutical, and cosmetic industries as a raw material but the inclusion level is still not much. Thus glycerol has an opportunity to be used as feed supplement and may serve as a source of energy. Glycerol or glycerin is generally recognized as safe for use in animal feed (FDA, 2006), especially for ruminant. However, it should be noted that the presence of impurities substances are at the acceptable level, such as the residual of methanol should not exceed 150 ppm, unsaponifiable matter not to exceed $2 \%$ (FDA, 2006), and negligible amount of mineral salts, catalysts, and other impurities so that it has no negative influence on animal health (Dasari, 2007).

Glycerol is indeed a normal component of animal metabolism that is produced through lipolysis of adipose tissue or blood lipoprotein, and there is no agreement on metabolic implications of exogenous supplementation of glycerol in the diet (Silva, 2014). It had been observed that glycerol supplementation improved glucose status in ruminants by acting as a gluconeogenic precursor that increased blood glucose level (Chung et al., 2007) and/or converted to glucose in the liver (Rémond et al., 1993). Glycerol is also readily absorbed through the rumen wall (Rémond et al., 1993) or fermented to propionic acid (Chung et al., 2007). Some in vitro studies related to glycerol supplementation in ruminant ration have been published, but the results are inconsistent in digestibility, total volatile fatty acid (VFA), $\mathrm{NH}_{3}-\mathrm{N}$, total gas, and methane $\left(\mathrm{CH}_{4}\right)$ production. The clearly resembled data is typically acetate to propionate ratio which is being lowered with the increasing level of glycerol in the diet (Rémond et al., 1993; Abo El-Nor et al., 2010; Krueger et al., 2010; Lee et al., 2011; Avila-Stagno et al., 2014). Many inconsistent outcomes between individual studies may be resulted from specific differences in experimental conditions.

Various data can be combined and analyzed by meta-analysis quantitatively in order to deal with such inconsistency. The objective of this study was, therefore, to evaluate the effect of glycerol supplementation on in vitro digestibility, ruminal fermentation characteristics, total gas and methane production through the metaanalysis approach.

\section{MATERIALS AND METHODS}

\section{Description of Database}

Database was constructed from published experiments listed in Scopus. The search used the following combination of two or more keywords: glycerol, glycerin, rumen, ruminant, and in vitro. A total of 11 publications, comprised of 13 studies and 42 treatments were obtained and used for the present meta-analysis (Table 1). All publications contained two or more glycerol supplementation levels which were studied in in vitro system (either batch or continuous culture system) with steer, cow or sheep as the donors of rumen fluid. Rumen fluid was obtained from the fistulated animals fed with forage and concentrate mixture with the ratio of 50:50 to 80:20 in all studies, with an exception of three studies fed with a single feed only. They were Krueger

Table 1. In vitro experiments included in the meta-analysis of the effect of glycerol levels on rumen fermentation

\begin{tabular}{|c|c|c|c|c|c|}
\hline Exp no. & Reference & In vitro type & Basal Feed & $\begin{array}{c}\text { Glycerol } \\
\text { content } \\
(\%)\end{array}$ & $\begin{array}{c}\text { Glycerol } \\
\text { level } \\
\text { (g/kg DM) }\end{array}$ \\
\hline 1 & Ramos \& Kerley 2012 & Continuous culture & Concentrate & - & $0-200$ \\
\hline 2 & Rico et al. 2012 & Continuous culture & $\mathrm{Tmr}$ & 65 & $0-124$ \\
\hline 3 & Avila-Stagno et al. 2014 & Rusitec & Brome hay and maize silage & 99.5 & $0-150$ \\
\hline 4 & Danielsson et al. 2014 & $\begin{array}{l}\text { Automated gas-production } \\
\text { system }\end{array}$ & Silage and concentrate & 99.5 & $0-163$ \\
\hline 5 & Abo el Nor et al. 2010 & Continuous culture & Alfalfa hay and concentrate & 99.5 & $0-108$ \\
\hline 6 & Krueger et al. 2010 & Gas-production system & Alfalfa hay & - & $0-400$ \\
\hline 7 & Avila et al. 2011 & Gas-production system & $\begin{array}{l}\text { Barley grain and barley } \\
\text { silage }\end{array}$ & 99.5 & $0-210$ \\
\hline 8 & Lee et al. 2011 & Gas-production system & Alfalfa hay & 99 & $0-182$ \\
\hline 9 & Lee et al. 2011 & Gas-production system & Corn grain & 99 & $0-188$ \\
\hline 10 & Meale et al. 2013 & Gas-production system & Total mixed ration (tmr) & 99.2 & $0-120$ \\
\hline 11 & AbuGhazaleh et al. 2010 & Continuous culture & Total mixed ration (tmr) & 99.5 & $0-108$ \\
\hline 12 & Rémond et al. 1993 & Fermenter & Wheat starch & - & $0-13.3$ \\
\hline 13 & Rémond et al. 1993 & Fermenter & Microgranular cellulose & - & $0-13.3$ \\
\hline
\end{tabular}


et al. (2010) and the two studies of Rémond et al. (1993) in which the cows were fed with Bermuda grass, maize silage or natural grassland hay, respectively. Glycerol used in the studies was crude glycerol with percentage of purity between $65 \%$ to $99.5 \%$ and in powder or liquid form. Glycerol was supplemented to substitute a main energy source such as corn (AbuGhazaleh et al., 2010; Abo el Nor et al., 2010; Ramos \& Kerley, 2012; Rico et al., 2012), wheat (Meale et al., 2013), barley grain (Avila et al., 2011), or maize silage (Avila-Stagno et al., 2014) or as an additive in ration (Danielsson et al., 2014). There was also glycerol addition into single feed such as alfalfa hay (Krueger et al., 2010; Lee et al., 2011), corn grain (Lee et al., 2011), and wheat starch or micro-granular cellulose (Rémond et al., 1993).

Parameters tabulated in this study were in vitro digestibility, ruminal fermentation characteristics, as well as total gas and methane production. The in vitro digestibility parameters were dry matter (DM) digestibility, organic matter (OM) digestibility, and neutral detergent fiber (NFD) digestibility. The ruminal fermentation characteristics included were total VFA; molar percentage of acetic $\left(\mathrm{C}_{2}\right)$, propionic $\left(\mathrm{C}_{3}\right)$, butyric $\left(\mathrm{C}_{4}\right)$, isobutyric (iso $\left.C_{4}\right)$, valeric $\left(C_{5}\right)$, and isovaleric (iso $C_{5}$ ) in total VFA; ratio of $\mathrm{C}_{2}$ to $\mathrm{C}_{3}$ by calculation; $\mathrm{pH}$ and ammonia concentration, total gas, methane, and microbial $\mathrm{N}$ production. Methane production values were taken from each paper and in case the parameter was not measured, it was calculated by using the stoichiometric formula outlined by Moss et al. (2000) since the formula has been proven to be accurate against direct measurement using a standard infrared methane analyzer (Jayanegara et al., 2015a).

\section{Statistical Analysis}

The analysis of data constructed in the database was conducted using a statistical meta-analysis approach (Sauvant et al., 2008; Jayanegara et al., 2014). The number of publication included in the database reflected the population of such in vitro study on glycerol supplementation from all period. Therefore, this present study assumed a fixed effect of various studies (Sauvant et al., 2008). The general linear model (GLM) procedure of SAS 9.1.3 was employed with the following model:

$$
\mathrm{Y}_{\mathrm{ij}}=\mathrm{B}_{0}+\mathrm{B}_{1} \mathrm{X}_{\mathrm{ij}}+\mathrm{s}_{\mathrm{i}}+\mathrm{e}_{\mathrm{ij}}
$$

where $\mathrm{Y}_{\mathrm{ij}}=$ dependent variable, $\mathrm{B}_{0}=$ overall intercept across all experiments (fixed effect), $B_{1}=$ linear regression coefficient of $Y$ on $X$ (fixed effect), $X_{i j}=$ value of the continuous predictor variable (glycerol supplementation level), $s_{i}=$ fixed effect of experiment $i$, and $e_{i j}=$ the unexplained residual error. The variable of experiment was declared in the class statement as it did not contain any quantitative information. In addition, the regression equations are also presented with p-value and root mean square error (RMSE).

\section{RESULTS}

\section{In Vitro Digestibility}

The equations of linear regressions between glycerol supplementation levels and in vitro digestibility parameters are presented in Table 2. Increasing levels of glycerol supplementation did not significantly affect in vitro dry matter digestibility (IVDMD), in vitro organic matter digestibility (IVOMD), and in vitro neutral detergent fiber digestibility (IVNDFD).

\section{Ruminal Fermentation Characteristics}

The effect of glycerol supplementation level on ruminal fermentation characteristics are presented in Table 3. Total VFA production was not changed by the increasing level of glycerol. Molar proportion of acetate and iso-valerate declined linearly $(\mathrm{P}<0.05)$ with the increasing level of glycerol, while on the contrary, molar proportion of propionate, butyrate, and valerate increased $(\mathrm{P}<0.05)$ linearly. The ratio of acetate to propionate thus significantly decreased $(\mathrm{P}<0.05)$ as the level of glycerol increased. Ruminal $\mathrm{pH}$ and ammonia concentration with the glycerol inclusion in the diet decreased linearly $(\mathrm{P}<0.05)$ with small and high magnitude effects relatively to their intercept values, respectively.

\section{Total Gas, Methane, and Microbial Protein Production}

The linear regression analyses between glycerol supplementation levels and total gas, methane, and microbial protein production are presented in Table 4. Glycerol inclusion in the ruminant diets increased the in vitro total gas production $(\mathrm{P}<0.05)$ at simultaneously lowered enteric methane emission $(\mathrm{P}<0.05)$. Glycerol supplementation had no effect on microbial protein production.

Table 2. Equations for linear regression of in vitro digestibility on dietary glycerol level

\begin{tabular}{lcccccccc}
\hline \multirow{2}{*}{$\begin{array}{l}\text { Response } \\
\text { variables }\end{array}$} & $\mathrm{n}$ & \multicolumn{9}{c}{ Variable estimates } \\
\cline { 3 - 10 } & & Intercept & SE intercept & $\mathrm{p}$ intercept & Slope & SE slope & $\mathrm{p} \mathrm{slope}$ & RMSE \\
\hline IVDMD (\%) & 19 & 72.5 & 2.42 & $<0.001$ & 0.0077 & 0.0160 & 0.637 & 3.84 \\
IVOMD (\%) & 8 & 56.1 & 1.47 & $<0.001$ & -0.0251 & 0.0140 & 0.128 & 2.38 \\
IVNDFD (\%) & 13 & 49.7 & 1.56 & $<0.001$ & 0.0003 & 0.0070 & 0.965 & 2.55 \\
\hline
\end{tabular}

Note: IVDMD= in vitro dry matter digestibility, IVOMD= in vitro organic matter digestibility, IVNDFD= in vitro neutral detergent fiber digestibility, $\mathrm{n}=$ number of treatment, $\mathrm{SE}=$ standard error, $\mathrm{RMSE}=$ residual mean square error. 
Table 3. Equations for linear regression of ruminal fermentation characteristics on dietary glycerol level

\begin{tabular}{lcccccccc}
\hline \multirow{2}{*}{ Response variables } & $\mathrm{n}$ & \multicolumn{9}{c}{ Variable estimates } \\
\cline { 3 - 9 } & & Intercept & SE intercept & $\mathrm{p}$ intercept & Slope & SE slope & $\mathrm{p} \mathrm{slope}$ & RMSE \\
\hline Total VFA (mmol/L) & 42 & 33.2 & 14.3 & 0.028 & 0.0559 & 0.0430 & 0.204 & 20.2 \\
$\mathrm{C}$ (\% total VFA) & 42 & 64.9 & 4.31 & $<0.001$ & -0.0589 & 0.0130 & $<0.001$ & 6.10 \\
$\mathrm{C} 3$ & 42 & 25.1 & 1.63 & $<0.001$ & 0.0404 & 0.0050 & $<0.001$ & 2.31 \\
$\mathrm{C} 4$ & 42 & 7.86 & 1.26 & $<0.001$ & 0.0132 & 0.0040 & 0.002 & 1.78 \\
iso-C4 & 23 & 0.69 & 0.086 & $<0.001$ & 0.00004 & 0.0004 & 0.928 & 0.17 \\
$\mathrm{C} 5$ & 30 & 2.57 & 0.365 & $<0.001$ & 0.0037 & 0.0020 & 0.039 & 0.71 \\
iso-C5 & 23 & 1.93 & 0.099 & $<0.001$ & -0.0012 & 0.0005 & 0.028 & 0.19 \\
$\mathrm{C} 2 / \mathrm{C3}$ & 42 & 2.04 & 0.137 & $<0.001$ & -0.0047 & 0.0006 & $<0.001$ & 0.27 \\
$\mathrm{pH}$ & 33 & 6.58 & 0.065 & $<0.001$ & -0.0008 & 0.0004 & 0.048 & 0.12 \\
$\mathrm{~N}-\mathrm{NH}_{3}(\mathrm{mmol} / \mathrm{L})$ & 28 & 5.70 & 1,076 & $<0.001$ & -0.0201 & 0.0060 & 0.006 & 2.04 \\
\hline
\end{tabular}

Note: $\mathrm{VFA}=$ volatile fatty acid, $\mathrm{C} 2=$ acetate, $\mathrm{C} 3=$ propionate, $\mathrm{C} 4=$ butyrate, $\mathrm{C} 5=$ valerate, $\mathrm{N}-\mathrm{NH}_{3}=$ nitrogen ammonia, $\mathrm{n}=\mathrm{number}$ of treatment, $\mathrm{SE}=$ standard error, RMSE= residual mean square error.

Table 4. Equations for linear regression of total gas, methane, and microbial protein production on dietary glycerol level

\begin{tabular}{lcccccccc}
\hline \multirow{2}{*}{ Response variables } & \multirow{n}{*}{} & \multicolumn{9}{c}{ Variable estimates } \\
\cline { 3 - 9 } & & Intercept & SE intercept & p intercept & Slope & SE slope & p slope & RMSE \\
\hline Total gas production (mL/g DM) & 15 & 109 & 12.5 & $<0.001$ & 0.2546 & 0.080 & 0.013 & 20.1 \\
CH4 (mmol/L) & 42 & 8.55 & 3.00 & 0.008 & -0.0258 & 0.009 & 0.008 & 4.24 \\
MPP (g/d) & 8 & 37.9 & 0.094 & $<0.001$ & 0.0002 & 0.0002 & 0.491 & 0.04 \\
\hline
\end{tabular}

Note: $\mathrm{CH} 4=$ methane, $\mathrm{MPP}=$ microbial protein production, $\mathrm{n}=$ number of treatment, $\mathrm{SE}=$ standard error, $\mathrm{RMSE}=$ residual mean square error.

\section{DISCUSSION}

Glycerol can be used to substitute or replace some parts of the energy source in ruminant diets without causing any detrimental effect on the digestibility. These results were in agreement with some previous studies in which glycerol as an energy substitution in diets had no effects on total tract digestibility of DM, OM (Khalili et al., 1997), and NDF (Schröder \& Südekum, 1999; Ramos \& Kerley, 2012). Similarly, no difference in OM digestibility was observed when glycerol was added or supplemented to wheat starch substrate (Rémond et al., 1993) and in NDF digestibility determined after $48 \mathrm{~h}$ incubation (Krueger et al., 2010).

Glycerol fermentation in the rumen has a propiogenic property (Rémond et al., 1993; Avila-Stagno et al., 2014) and produces a high level of butyrate (Czerkawski \& Breckenridge, 1972) at the expense of acetate. The increasing molar proportion of propionate and towards the decreased ratio of acetate to propionate responses were also in agreement with a number of previous publications on addition of glycerol into starch-rich ration (Rico et al., 2012; Meale et al., 2013), or forage substrates (Krueger et al., 2010; Lee et al., 2011), as well as in vivo in the beef cattle (Wang et al., 2009) and dairy cows (Carvalho et al., 2011). Ramos \& Kerley (2012) concluded that glycerol was selectively used by rumen microbes for producing propionate rather than acetate. It was also supported by Bergner et al. (1995) who showed the most of 14C labeled glycerol was found in propionate form. Propionate is one of the main glucogenic precursors thus increasing the glucose availability as an energy supply for animal. The increase of valerate with the increasing level of glycerol is apparently related to an enhancing proportion of propionate in the rumen since the former is synthesized from the latter (Hungate, 1966).

The mean of ruminal $\mathrm{pH}$ showed a normal rumen environment. The lower ruminal $\mathrm{pH}$ due to higher glycerol level was probably due to the tendency for a higher total VFA concentration (Wang et al., 2009; Rico et al., 2012) although it was not significant in our present study. However, it has to be noted that a declining ruminal $\mathrm{pH}$ depends on the proportion of glycerol-starch substitution and the types of basal diet. The decrease of ammonia concentration can be explained by a lower proteolysis and/or deamination occurred during ruminal fermentation. Lower deamination due to glycerol is supported by the decrease in iso-valerate as a product of branched-chain amino acids fermentation (Andries et al., 1987).

The increase of gas production with glycerol inclusion in the diets was in agreement with the study of Krueger et al. (2010) that reported a linear increase in gas production when glycerol was added to alfalfa hay. In contrast, the increasing level of glycerol supplementation in the diet had no effect on gas production kinetics or cumulative gas production at $24 \mathrm{~h}$ (Meale et al., 2013) and a reduction in gas production occurred when glyc- 
erol is used to substitute alfalfa hay or corn grain (Lee $e t$ al., 2011). It was possibly because the glycerol fermentation had a long lag time and a slow rate of kinetics of gas production (Ferraro et al., 2009; Lee et al., 2011). However, it is difficult to explain how the total gas production can be increased when no differences for in vitro digestibility and total VFA, lower enteric $\mathrm{CH}_{4}$, and less value for ratio of acetate to propionate. Propionate production as the end product of fermentation deliver less gas than acetate (Blümmel et al., 1997). In addition, we did not measure a quantitatively meta-analysis of kinetics of gas production.

Lower methane production by the increasing level of glycerol was similarly observed by Lee et al. (2011) who declared that glycerol reduced enteric $\mathrm{CH}_{4}$ production from feeds while maintaining animal production. It is associated with the decline ratio of acetate to propionate. Glycerol is fermented towards more propionate in the rumen and serves as a hydrogen sink, a main substrate for methanogenesis (Jayanegara et al., 2015b). Propiogenic substrates have been proposed as methane abatement strategy (Beauchemin et al., 2008; Jayanegara et al., 2014). Depression of methanogenesis may be related to a long lag time for glycerol fermentation (Lee et al., 2011) so that rumen microbes especially methanogens need more time to get adapted. When they have settled and successfully adapted, the is a possibility that they would ferment glycerol and produce methane. So far there is no recommendation on supplementing glycerol in vivo for a longer time period or a whole life time of animal.

\section{CONCLUSION}

Glycerol is apparently appropriate to be used as an energy source in the ruminant diets. Ruminal fermentation of glycerol inclusion was identified to have no detrimental effects in the rumen and environmentally friendly as shown by the increase in molar proportion of propionate and the decrease in acetate without affecting the in vitro digestibility and microbial protein production, and concomitantly decrease methane production. However, further studies are needed to investigate the effects of glycerol supplementation for microbial adaptation and its usage in a long term in vivo study.

\section{REFERENCES}

Abo El-Nor, S., A. A. AbuGhazaleh, R. B. Potu, D. Hastings, \& M. S. A. Khattab. 2010. Effects of differing levels of glycerol on rumen fermentation and bacteria. Anim. Feed Sci. Technol. 162: 99-105. http://dx.doi.org/10.1016/j. anifeedsci.2010.09.012

AbuGhazaleh, A. A., S. Abo El-Nor, \& S. A. Ibrahim. 2011. The effect of replacing corn with glycerol on ruminal bacteria in continuous culture fermenters. J. Anim. Phys. Nutr. 95: 313-319. http://dx.doi.org/10.1111/j.1439-0396.2010.01056.x

Andries, J. L., F. X. Buysse, D. L. De Brabander, \& B. G. Cottyn. 1987. Isoacids in ruminant nutrition: their role in ruminal and intermediary metabolism and possible influenced on performance - a review. Anim. Feed Sci. Technol. 18: 169180. http://dx.doi.org/10.1016/0377-8401(87)90069-1

Avila, J. S., A. V. Chaves, M. Hernandez-Calva, K. A.
Beauchemin, S. M. McGinn, Y. Wang, O. M. Harstad, \& T. A. McAllister. 2011. Effects of replacing barley grain in feedlot diets with increasing levels of glycerol on in vitro fermentation and methane production. Anim. Feed Sci. Technol. 166-167: 265-268. http://dx.doi.org/10.1016/j. anifeedsci.2011.04.016

Avila-Stagno, J., A. V. Chaves, G. O. Ribeiro Jr, E. M. Ungerfeld, \& T. A. McAllister. 2014. Inclusion of glycerol in forage diets increases methane production in a rumen simulation technique system. British J. Nutr. 111: 829-835. http://dx.doi.org/10.1017/S0007114513003206

Beauchemin, K. A., M. Kreuzer, F. O'Mara, \& T. A. McAllister. 2008. Nutritional management for enteric methane abatement: a review. Austr. J. Exp. Agric. 48: 21-27. http://dx.doi. org/10.1071/EA07199

Bergner, H., C. Kijora, Z. Ceresnakova, \& J. Szakacs. 1995. In vitro studies on glycerol transformation by rumen microorganism. Arch Tierernahr. 48: 245-256. http://dx.doi.org/10.1080/17450399509381845

Blümmel, M., H. P. S. Makkar, \& K. Becker. 1997. In vitro gas production: A technique revisited. J. Anim. Physiol. Anim. Nutr. 77: 24-34. http://dx.doi.org/10.1111/j.1439-0396.1997.tb00734.x

Carvalho, E. R., N. S. Schmelz-Roberts, H. M. White, P. H. Doane, \& S. S. Donkin. 2011. Replacing corn with glycerol in diets for transition dairy cows. J. Dairy Sci. 94: 908-916. http://dx.doi.org/10.3168/jds.2010-3581

Chung, Y. H., D. E. Rico, C. M. Martinez, T. W. Cassidy, V. Noirot, A. Ames, \& G. A. Varga. 2007. Effects of feeding dry glycerin to early postpartum holstein dairy cows on lactational performance and metabolic profiles. J. Dairy Sci. 90: 5682-5691. http://dx.doi.org/10.3168/jds.2007-0426

Czerkawski, J. W. \& G. Breckenridge. 1972. Fermentation of various glycolytic intermediates and other compounds by rumen micro-organisms, with particular reference to methane production. Brit. J. Nutr. 27: 131-146. http://dx.doi.org/10.1079/BJN19720077

Danielsson, R., A. Werner-Omazic, M. Ramin, A. Schnürer, M. Griinari, J. Dicksved, \& J. Bertilsson. 2014. Effects on enteric methane production and bacterial and archaeal communities by the addition of chasew nut shell extract or glycerol-An in vitro evaluation. J. Dairy Sci. 97: 5729-5741. http://dx.doi.org/10.3168/jds.2014-7929

Dasari, M. 2007. Crude glycerol potential described. Feedstuffs. Vol. 79, No. 43, October 15.

[FDA] Food and Drug Administration. 2006. Code of Federal Regulations, 21CFR582.1320, Title 21, Vol. 6, 2006. 21CFR582.1320.

Ferraro, S. M., G. D. Mendoza, L. A. Miranda, \& C. G. Gutiérrez. 2009. In vitro gas production and ruminal fermentation of glycerol, propylene glycol and molasses. Anim. Feed Sci. Technol. 154: 112-118. http://dx.doi. org/10.1016/j.anifeedsci.2009.07.009

Hungate, R. E. 1966. Quantities of carbohydrate fermentation products. Page 245 in Rumen and Its Microbes. R. E. Hungate, ed. Academic Press, New York, NY. http://dx.doi.org/10.1016/B978-1-4832-3308-6.50009-7

Jayanegara, A., E. Wina, \& J. Takahashi. 2014. Meta-analysis on methane mitigating properties of saponin-rich sources in the rumen: influence of addition levels and plant sources. Asian-Australas. J. Anim. Sci. 27: 1426-1435. http://dx.doi.org/10.5713/ajas.2014.14086

Jayanegara, A., H. P. S. Makkar, \& K. Becker. 2015a. Addition of purified tannin sources and polyethylene glycol treatment on methane emission and rumen fermentation in vitro. Med. Pet. 38: 57-63. http://dx.doi.org/10.5398/ medpet.2015.38.1.57

Jayanegara, A., G. Goel, H. P. S. Makkar, \& K. Becker. 2015b. Divergence between purified hydrolysable and 
condensed tannin effects on methane emission, rumen fermentation and microbial population in vitro. Anim. Feed Sci. Technol. 209: 60-68. http://dx.doi.org/10.1016/j. anifeedsci.2015.08.002

Khalili, H., T. Varvikko, V. Toivonen, K. Hissa, \& M. Suvitie. 1997. The effects of added glycerol or unprotected free fatty acids or a combination of the two on silage intake, milk production, rumen fermentation and diet digestibility in cows given grass silage based diets. Agr. Food Sci. 6: 349-362.

Krueger, N. A., R. C. Anderson, L. O. Tedeschi, T. R. Callaway, T. S. Edrington, \& D. J. Nisbet. 2010. Evaluation of feeding glycerol on free-fatty acid production and fermentation kinetics of mixed ruminal microbes in vitro. Biores. Technol. 101: 8469-8472. http://dx.doi.org/10.1016/j. biortech.2010.06.010

Lee, S. Y., S. M. Lee, Y. B. Cho, D. K. Kam, S. C. Lee, C. H. Kim, \& S. Seo. 2011. Glycerol as a feed supplement for ruminants: In vitro fermentation characteristic and methane production. Anim. Feed Sci. Technol. 166-167: 269-274. http://dx.doi.org/10.1016/j.anifeedsci.2011.04.070

Meale, S. J., A. V. Chaves, S. Ding, R. D. Bush, \& T. A. McAllister. 2013. Effects of crude glycerin supplementation on wool production, feeding behavior, and body condition of Merino ewes. J. Anim. Sci. 91: 878-885. http://dx.doi.org/10.2527/jas.2012-5791

Moss, A. R., J. P. Jouany, \& J. Newbold. 2000. Methane production by ruminants: its contribution to global warming. Anales de Zootechnie. 49: 231-253. http://dx.doi.org/10.1051/animres:2000119

Quispe, C. A. G., C. J. R. Coronado, \& J. A. Carvalho Jr. 2013. Glycerol: production, consumption, prices, characterization and new trends in combustion. Renew. Sustain. Energy Rev. 27: 275-293. http://dx.doi.org/10.1016/j. rser.2013.06.017
Ramos, M.H. \& M. S. Kerley. 2012. Effect of dietary crude glycerol level on ruminal fermentation in continues culture and growth performance of beef calves. J. Anim. Sci. 90: 892-899. http://dx.doi.org/10.2527/jas.2011-4099

Rémond, B., E. Souday, \& J. P. Jouany. 1993. In vitro and in vivo fermentation of glycerol by rumen microbes. Anim. Feed Sci. Technol. 41: 121-132. http://dx.doi.org/10.1016/0377-8401(93)90118-4

Rico, D. E., Y. H. Chung, C. M. Martinez, T. W. Cassidy, K. S. Heyler, \& G. A. Varga. 2012. Effects of partially replacing dietary starch with dry glycerol in a lactating cow diet on ruminal fermentation during continuous culture. J. Dairy Sci. 95: 3310-3317. http://dx.doi.org/10.3168/jds.2011-5059

Sauvant, D., P. Schmidely, J. J. Daudin, \& N. R. St-Pierre. 2008. Meta-analyses of experimental data in animal nutrition. Animal 2: 1203-1214. http://dx.doi.org/10.1017/S1751731108002280

Schröder, A. \& K. H. Südekum. 1999. Glycerol as a by-product of biodiesel production in diets for ruminants. Paper no. 241 in New Horizons for an Old Crop. Proc. 10th Int. Rapeseed Congr., Canberra, Australia. N. Wratten and P. A. Salisbury, ed. The Regional Institute Ltd., Gosford, New South Wales, Australia.

Silva, V. O., E. Lopes, E. F. Andrade, R. V. Sousa, M. G. Zangeronimo, \& L. J.Pereira. 2014. Use of biodiesel co-products (glycerol) as alternative sources of energy in animal nutrition: a systematic review. Arch. Med. Vet. 46: 111-120. http://dx.doi.org/10.4067/S0301-732X2014000100015

Wang, C., Q. Liu, W. J. Huo, W. Z. Yang, K. H. Dong, Y. X. Huang, \& G. Guo. 2009. Effects of glycerol on rumen fermentation, urinary excretion of purine derivatives and feed digestibility in steers. Livest. Sci. 121: 15-20. http://dx.doi.org/10.1016/j.livsci.2008.05.010 